\title{
CONCEPTUAL REASONING FOR DIDACTICS OF AUGMENTED REALITY TEACHING / LEARNING PLATFORM: SOME PRELIMINARY IDEAS ${ }^{1}$
}

\author{
Vincentas Lamanauskas, Margarita Vilkonienè, \\ Rytis Vilkonis
}

Natural Science Education Research Centre, Šiauliai University, Lithuania

\begin{abstract}
The problematics of Information and Communication Technologies is undoubtedly important area in modern education. The world rapidly changes and technical potentiality is constantly growing. The digital revolution is making life easier for people in both directions work and leisure time. A question if we can support an idea that modern ICT helps with the educational process is not explicit? Obviously, ICT improvement leads to applying them in different areas of our life.

On the one hand, the educational environment of ICT implementation plays a major role. Possessing modern ICT cannot be the only factor as in order to improve the educational process we need to know the ways of using them i.e. it should not be a matter of fashion. On the other hand, ICT (audiovisual, computer, interactive etc.) themselves are the objects of thorough investigations. So, an international scientific project ARiSE could be the best example (http://www.arise-project.org). Seven institutions from five European countries including Germany, Lithuania, the Czech Republic, Romania and Malta are the participants of the event. The coordinator of the project is Fraunhofer-Institut IAIS (Fraunhofer Institut Intelligente Analyse - und Informationssysteme, Sankt Augustin, Germany) (http://www.iais.fraunhofer.de/). The main objective of the ARiSE Project is to test the pedagogical effectiveness of introducing augmented reality $(A R)$ into the classroom and creating remote collaboration between classes around AR display systems.

Also, the important task is to develop a pedagogical reasoning of the given augmented reality technology in school environments. In this article the first conceptual ideas on this question are presented. Key words: science education, augmented reality, school environment.
\end{abstract}

\section{Introduction}

ICT improvement leads to applying them in different areas of our life. However, "transferring"them to the educational system seems to be the most difficult problem. A question if we can support an idea that modern ICT helps with the educational process is on explicit? (Lamanauskas, 2006). S. Papert (1980) thinks that from most information technologies, including television and printed books, existence of the computers may have the main influence on educational process. The computer creates a qualitatively new relation between those who are studying and an important area of knowledge - knowledge is being acquired having a clear aim. Studying becomes more active and self-dependent. Hereby, this knowledge forms child's intellect.

Surely, existence of the computer is not a satisfactory guarantee that this contact will appear. In most schools and families children experience completely different things. In most cases the computer is used for playing games or as "a machine for studying"to fulfill the assigned tasks. This problem of the computer technology usage is very relevant.

It's obvious, that the situation in the ICT practicing sphere is constantly changing. Things which are happening in the education system nowadays is just an empirical question. Things which may happen is a technical question. Things which will really happen is a political question, and it will depend on many social decisions which will be enacted by the

1 This research is carried out within the frames of international FP6 scientific project "ARiSE", http://www.arise-project.org 
funds, companies, schools and separate individuals who will choose their career in this activity sphere and children who will also decide what to accept and what to do with this innovation.

It is common to think that ICT is an innovation in the educational system. However, an innovation is only the idea which is completely new. Besides, to be a "most important "innovation, an innovation has to be an idea that is very widely used and is critically important where it applies. Innovations that are only used by a very small proportion of software (or software users) aren't included (David and Wheeler, 2007). Unfortunately, we have to state that conservative ideas in the educational system are becoming a renewed social phenomenon. Notably, that conservative tendencies of the computer usage in education is often "fitted" into other new technologies. The biggest part of things which are now called "teaching technologies" or "practicing computers in education" is just the combination of the old teaching methods and the new means of technologies.

A typical problem has been how to engage students with appropriate information and communication technologies (ICT) during the learning process (Liarokapis et al., 2004).

There are different possibilities of how a computer can contribute to teaching and learning. A very simple solution is to use a computer as playback media, taking advantage of the multimedia capabilities of the device. E-learning platforms hold additional features depending on the solution they are aiming at. A classical setup involves one computer for one person without any contact to anybody else or the environment. This situation is called "isolated learning" (Lyotard, 1993).

However, learning is fundamentally built up through conversations between persons or among groups, involving the creation and interpretation of communication. Thus, conversations are means by which people collaboratively construct beliefs and meanings as well as state their differences. Learning involves making sense of experience, thought, or phenomenon in context. Student representation or understanding of a concept is not abstract and self-sufficient, but rather it is constructed from the social and physical context in which the concept is found and used. Brown et al. (1989) emphasized the importance of implicit knowledge in developing understanding rather than acquiring formal concepts. It is, therefore, essential to provide students with authentic experiences with the concept. Students can engage in learning conversations in distributed multimedia environments. Multimedia technologies, such as graphics, simulations, video, sound and text, allow instructors to use multiple modes and representations to construct new understanding and conceptual change of enhancing student knowledge (Butcher-Powell, 2004). According to Azuma (1997), AR supplements reality, rather than completely replacing it. AR systems are featuring an integration of real and virtual (computer generated images) into real environments, real time $3 \mathrm{D}$ interaction and targeting all senses (visual, auditory and haptic).

\section{Goals of the project "ARiSE"}

The primary purpose of the international research project ARiSE (Augmented Reality in School Environments) is to test pedagogical effectiveness of introducing augmented reality (AR) into the comprehensive school and creating remote collaboration between classes around the AR display systems. Project "ARiSE" will develop an AR teaching/learning platform and associated pedagogical scenarios of use, enabling teachers to promote new teaching practices for teaching scientific and cultural content in primary and secondary school. The aim of the project is to offer to the group of students the possibility of ,playing“with virtual objects and thereby to perform learning by doing instead of learning by reading. 


\section{Augmented-Reality-Teaching Platform: interactive AR display system}

The heart of the Augmented-Reality-Teaching Platform is the interactive AR display system and the software operating it. Starting from an existing AR display, that was created for museums and is available on the market since 2003, the new display system will evolve with a few but important modifications needed to overcome its 'museum legacy' (DofW, 2005).

Table 1. The main sources about Augmented Reality.

\begin{tabular}{|l|l|}
\hline \multicolumn{1}{|c|}{ Title } & \multicolumn{1}{c|}{ Web address } \\
\hline ARiSE & $\underline{\text { http://www.iais.fraunhofer.de/arise.html?\&L=1 }}$ \\
\hline $\begin{array}{l}\text { Introduction to Augmented } \\
\text { Reality }\end{array}$ & $\underline{\text { http://www.se.rit.edu/ jrv/research/ar/introduction.html }}$ \\
\hline Augmented Reality Page & $\underline{\text { http://www.se.rit.edu/ jrv/research/ar/ }}$ \\
\hline $\begin{array}{l}\text { How Augmented Reality } \\
\text { Will Work }\end{array}$ & $\underline{\text { http://www.howstuffworks.com/augmented-reality.htm }}$ \\
\hline $\begin{array}{l}\text { Registration Errors in } \\
\text { Augmented Reality }\end{array}$ & $\underline{\text { http://www.cs.unc.edu/ azuma/azuma AR.html }}$ \\
\hline $\begin{array}{l}\text { Augmented Reality Technology } \\
\text { Promises Breakthroughs In } \\
\text { Education And Cognitive } \\
\text { Potential }\end{array}$ & $\underline{\text { http://www.newstarget.com/000444.html }}$ \\
\hline $\begin{array}{l}\text { Augmented Reality and } \\
\text { Education: } \\
\text { Current Projects and the } \\
\text { Potential for Classroom } \\
\text { Learning }\end{array}$ & $\underline{\text { http://www.newhorizons.org/strategies/technology/shelton.htm }}$ \\
\hline Augmented Reality & \\
\hline
\end{tabular}

The Augmented-Reality-Teaching platform (consisting of display system and software) will raise teaching technology for basic, middle, and high schools to a new level of possibilities. The platform itself is built with standard PCs and some extensions (Picture 1).

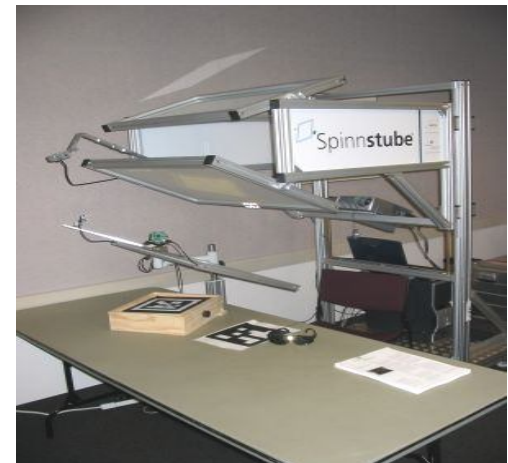

a)

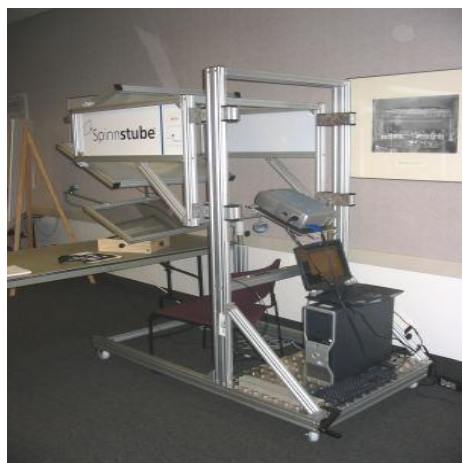

b)

Picture 1. The module of the AR teaching /learning platform from the front (a) and from the back (b).

With the help of augmented reality (AR) a class can work in a team collaboratively and benefit from state of the art technology. Real objects are superimposed with virtual images to better explain processes in 3 dimensional setups. Students interact with the AR-system and 
with each other making learning a team-work experience and not a teacher's show. Even remote collaboration with classes from other countries will be possible by using video conferencing capabilities of the system (Muehl, 2005). The students (users) using the AR teaching /learning platform must wear stereo glasses and headphones.

The platform will be based on existing open eLearning software with a user-centred interface added on to it which allows innovative use of augmented reality in schools. It has a strong focus on collaborative use on different levels.

The learners are able simultaneously perform different actions with real and virtual objects (on the table and real objects rather than on a computer monitor screen). In this case, the students can be better made aware of the processes taking place, structure and functions of the examined object. The left side of the picture 2 shows building a new learning platform of augmented reality, the right one presents an example of a mixed environment (real and virtual). The top of the picture (b) points to real objects only whereas at the bottom, the real objects supplemented with the virtual ones generated by computer are placed.

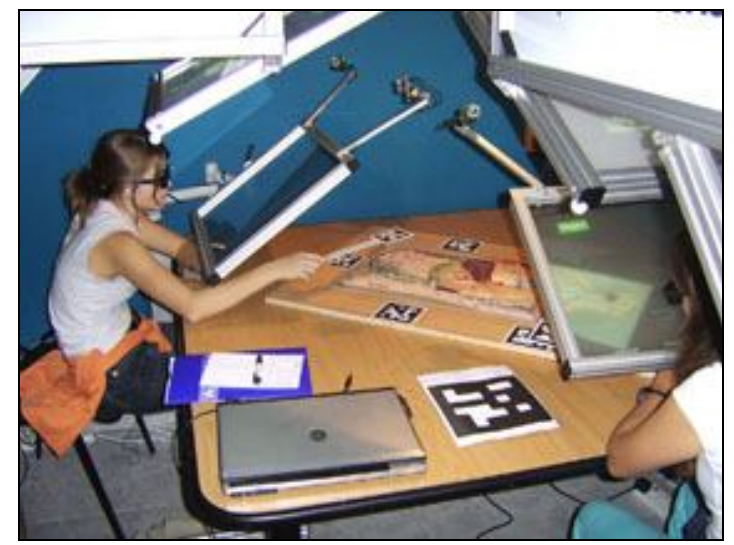

a)
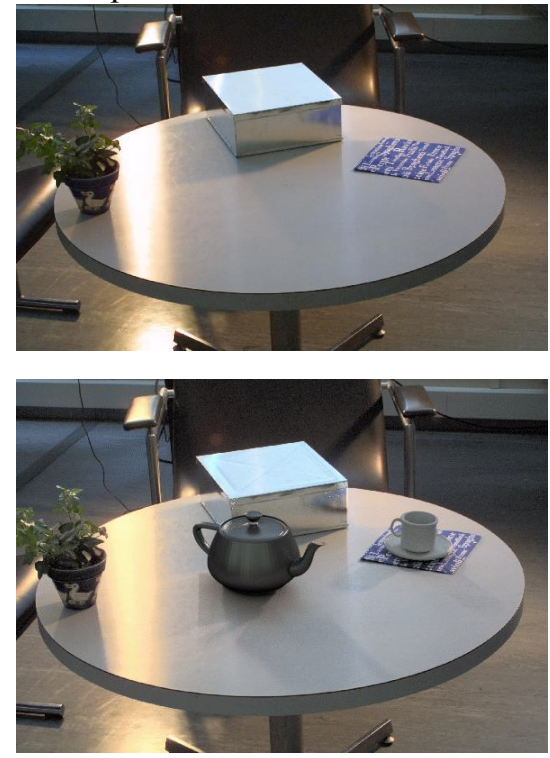

b)

Picture 2. The learners manipulating with real object (a); virtual augmentation (b).

Different actions can be made by the learners manipulating with real objects (for example, models, moulages and other training aids) and virtual augmentation (for example, objects, symbols, text etc.). The main point is to make the identified topics clearer and more understandable.

Some preliminary results regarding the educational value of the new teaching / learning platform based on Augmented Reality Technology for school environments were published (Lamanauskas, Vilkonis, 2007). The evaluation of the new AR teaching learning platform from a pedagogical point of view will be enlarged in the future.

\section{Innovative aspects}

The life of society is nowadays often influenced by the new styles of thinking and working, non-traditional manners and new ideology. Life at school is varied by eclectic formations - the combining and using different contradictory concepts of science and art, technologies, styles, theses and ideas. This way the ideas of postmodernism are being 
expressed in the society, and these ideas stimulate the alternation and the innovative processes which are described as a driving force of the modern life of society (Duobliene, 2006).

It is possible, that applying of the ,ARiSE“teaching/learning platform in school would give some innovation to educational process on the whole. Firstly, it would get evidence through changing of the studying surroundings. Appealing the ideas of postmodernism, we may suppose that creation of the studying surroundings provided with the new information technologies should become one of the goals for development of general education. This way the active processes of cognition would be stimulated. „ARiSE“teaching/learning platform is a technology which gives especially bright illusion to a professional scientific activity and hereby stimulates the students to study positively and purposefully. According to S. Papert (1980), things which happen to the professionals can also be applied to the children. In most schools a computer is treated as a teaching instrument but not as a subsidiary device for a child when he is studying. This difference is not insignificant and related only with the methodological choice of one out of two teaching strategies. It reflects the main differences among the pedagogical philosophies, i.e. the differences among attitudes to the natural childhood. The computer as a subsidiary device while studying gives the child a possibility to become more like the adults, having in mind his relation with his own intellectual products and with himself. So, likely, that „ARiSE“ teaching/learning platform, being the subsidiary device for the student to learn actively and purposefully, could neutralize the manifestations of „,infantilisation“ which often occur in schools (Papert, 1980).

Besides, in modern pedagogic the concept of ,situated cognition“is used more often than before. This concept is used by the pedagogical trend which appeals to the situation influence on the studying results. According to this theory, the surroundings of studying and working are not the accidental conditions in which the actions, not depending upon the situation, are done. Contrarily, cognition is a multiple process which is subjectively interpreted by the individual and including physical and social contexts. That's why it will be useful to concentrate one's attention on the technical providing of the educational process with the modern technical means and on creating the modern studying surroundings which give to studying variety, attraction, pleasure and relevance Brill, 2001; Ignatova, 2007). Considering the fact that a personal computer for most of modern students (in European countries) is not a new thing, we can do a presumption that the creation of a new learning platform which would essentially change the learning surrounding will be a significant contribution towards prompting students' interest in Natural Sciences.

\section{Visualisation}

The formation of images and concepts are the essential components of Natural Science education (Lamanauskas, 2003). Images are the prospects of the things or phenomena which were perceived before. Images are very important in the process of the Natural Science education. We can form the images of the natural objects, phenomena and processes in two ways - direct and intermediate. The images are formed directly by immediately observing and researching natural objects of the natural surrounding, their models, natural or unnaturally caused phenomena or processes. The images are formed intermediately appealing to teacher's story, a text, the pictures of natural objects and phenomena, and before stored true-life experience which, as researches show, often forms the nonscientific images (Slekiene, 2006; Osborne and Fryberg, 1991). In the education process it is difficult to form the concepts on the basis of such images. The teacher has not only to form the new images but also to correct the existing ones.

Though both ways of forming the images (direct and intermediate) can be combined, the direct way is more useful. When forming the images by using the intermediate way there is a greater probability that the wrong image will be formed and then, on its basis, the wrong 
concept will be formed, too. Nowadays in the Natural Science education there dominates the intermediate way of forming the images because contemporary education system does not make conditions, except Primary School, to observe natural phenomena directly: in the educational process there dominates the 45 minutes lesson form. We are short of time to explore the outdoor fields, and in town schools there is not a sufficient surrounding, either. The new laws restrict storage and usage of the chemical agents in schools, so the children lose possibility to observe unnaturally caused natural phenomena and processes. In the same way, the education process loses searching, hypothesizing and checking. The only possibility to use the models of the natural objects and to look for possibilities in using modern informational communication technologies (ICT) is left.

Models can function as a bridge between scientific theory and the world-as-experienced (,reality“) in two ways. They can act, as outlined above, as simplified depictions of a realityas-observed (exemplar phenomena), produced for specific purposes, to whish the abstractions of theory are then applied. They can also be idealizations of a reality-as-imagined, based an the abstractions of theory, produced so that comparisons with reality-as-observed can then be made. In this latter way they are used both to make abstractions visible (Francoeur, 1997), and, crucially, to provide the basis for predictions about, and hence scientific explanations of phenomena (Gilbert, Boulter, \& Rutherford, 2000). This wide range of function is made possible because models can depict many different classes of entities, covering both the macro and sub-micro levels of representation. Many models are of objects which are viewed as having either an independent existence (e.g. a drawing of a reaction flask, of an atom) or as being part of a system (e.g. a drawing of a reaction flask in an equipment train, of an atom in a molecule). The examples were drawn from chemistry. This is not surprising - for the key role of models in the development of chemical knowledge was recognised by the mid-twentieth century (Bailer-Jones, 1999; Francoeur, 1997). The development and widespread use of computer-based systems for generating and displaying models had its initial impact on chemistry, where visualization is so vital.

If models play important roles in science, it therefore follows that they should play equally important roles in science education. Those students must understand the nature and significance of the models that played key roles in the development of their chosen subject. Models are equally important in the education of the majority who will need some level of „,scientific literacy“ for late life (Laugksch, 2000).

On major aspect of „learning science“ (Hodson, 1992) is the formation of mental models and the production of expressed models by individual students that are as close to scientific or historical models a sis possible. To this end, simplified versions of scientific or historical models may be produced as curricular models (for example, the widely used dot-and-cross version of the Lewis-Kossel model of the atom) that are then taught. Specially developed teaching models are created to support the learning of particular curricular models (for example, the analogy, the atom as the solar planetary system"used in the lower secondary/junior high school) (Gilbert et al., 2000). The models can be material, verbal, symbolic and visual.

The concrete (or material) model is three-dimensional and made of resistant materials e.g. a plastic ball-and-stick model of an ion lattice, a plaster representation of a section through geological strata.

The verbal model can consist of a description of the entities and the relationships between them in a representation e.g. of the natures of the balls and sticks in a ball-and-stick representation. It can also consist of an exploration of the metaphors and analogies on which the modeli s based, e.g. „covalent bonding involves the sharing of electrons“as differently represented by a stick in a ball-and-stick representation and in a space-filling representation. Both versions can be either spoken or written. 
The symbolic model consists of chemical symbols and formula, chemical equations, and mathematical expressions, particularly mathematical equations e.g. the universal gas law, the reaction rate laws.

The visual model makes use of graphs, diagrams, and animations. Two-dimensional representations of chemical structures (,diagrams“) are universal examples. Those pseudo three - dimensional representations produced by computers, that figure so prominently in this book, which may be termed „virtual models“, also fall into this category.

A new learning / teaching platform created by the "ARiSE" project is predicted on AR technology and hypothetically considered as a new possibility to seek for more precise formation of Natural Science images and concepts in Comprehensive School. This new learning platform should be especially useful and necessary actualizing introductory courses of Natural Science, which from the very beginning require abstract thinking. Meanwhile, at this age students'abstract thinking is still in the stage of formation. This factor at this time blocks the assimilation of Natural Science basis. Later it blocks the assimilation of the remaining learning course.

The AR teaching / learning platform which is being created should not only stimulate children to take interest in the subject and stimulate learning motivation, but also help the students to understand invisible and untouchable, that's why hardly understandable, cognitive objects.

Where as a big part of the knowledge of Natural Sciences is analyzed by using different means of the samples and modeling, the learning platform which is being created by the project "ARiSE" should make a better possibility for the students to understand particular models of natural objects or processes, and, on their basis, natural objects and processes. The models are most often used in Biology and Chemistry. That's why Biology was chosen for the first "ARiSE" teaching / learning platform prototype and Chemistry - for the second. Considering that the real cognition objects which are invisible with the naked eye, a real object for virtual addition is chosen also the model of the object. A missing part of the object or particular processes connected with the object are added virtually.

The fact that virtual information is combined with the real object, which can be seen, touched and controlled at a particular level (turn, raise and so on) the same as virtual addition, lets us make an assumption that "ARiSE" teaching / learning platform, which is being created, will give us possibility to make the abstract cognition objects more concrete. I.e. verbal, symbolical and visual samples which are now dominating in schools make closer to material, more touchable and concrete samples. Herewith, giving more possibilities of imagery and manipulation to the samples.

\section{The Possibility of Cooperation}

When discussing the innovative aspects of the applying "ARiSE" teaching / learning platform, it was mentioned that cognition involves not only physical but also social contexts. That's why implementing self-education process it is useful to concentrate one's attention on the emotional setting of the lesson (what is student's mood? What is the culture of relationship among the students in the class?). Now that the computers are intruding into our lives, there is fear that they will bring alienation among people. But as experience shows, information technology deliberately included into the social system, can radically change not only the formation of intellect but also people's way of life (Papert, 1980).

Considering above-mentioned experience, we may think that applying "ARiSE" teaching / learning platform in the self-educational process will create conditions for the students to communicate more among themselves and the teachers. It will happen so because work will be organized while cooperating in pairs or small groups. It is a very important moment because, according to the representatives of postmodernism, the self-educational 
process is, in many cases, more important than the result itself. Such lingual activity as discussions or questioning should take a special place in the educational process (Lyotard, 1993; Rorty, 1997). In this place it is worth remembering the difference, emphasized by S. Papert, between the two possibilities how can ICT enrich thought and how it can change the way of gaining knowledge. Applying the technology of augmented reality, the most favourable conditions to gain the knowledge while discussing, cooperating, consulting, trying and finding, i.e. interacting with the surroundings and the people round about, will be created.

Appealing hermeneutics, one of the dominating trends in modern philosophy, which researches the phenomena of perception (it is also called the theory of interpretation and perception) it is obvious, that namely, during the above-mentioned conditions there happen especially significant processes of perception. Namely communication stimulates perception of the texts, phenomena, objects and processes. The well-perceived subjects are the basis to upstart the scientific cognition, and that is relevant for a Comprehensive School where the method of the scientific cognition, which creates conditions for the scientific cognition of the particular level, is regulated too. According to Gallagher (1992) and Gadamer (1989) the truth comes out of the relation between the scientific object and subject. To perceive the abovementioned relation the thought is needed.

While learning with "ARiSE" teaching / learning platform, there are planned five possibilities of cooperation: a) 2 students; b) 2 students and a teacher; c) 4 students d) 4 students and a teacher; 2-4 students and a teacher from the one country and 2-4 students and a teacher from the other country. The teacher is a tutor and mentor. If there is no teacher the computer gives the tasks.

\section{Constructive learning}

Constructive learning / teaching emphasizes thinking and points that the student actively constructs and develops his knowledge himself depending on his interaction with the objects, the teachers and contemporaries (Wellington, 1996; Driver, 1989; Holding et al., 1992; Glasersfeld, 1991). Beginning from the direct student's experience, later more various contexts are discovered and wider generalization is made. Thereby, the systematic profiles of the subject become clear. According constructivism, the knowledge is not final, static and ready for conveying. Later, the knowing is partially personal (subjective) and the meaning is being constructed by students themselves appealing their own experience (Šlekiene, 2006; Arends, 1998).

Appealing the ideas of constructivism, the relation between the student and his teacher changes. The teacher becomes not a person who imparts the knowledge but a person who is students' mentor and a proficient of his field. The teacher supervises and helps. The student is not a passive knowledge receiver but an active constructor who constructs all the knowledge about the outer world. The teacher accepting these ideas has to accept the condition that every student will apply the offered learning methods, strategies and means individually. The students are now more responsible for the planning, ruling and controlling their education process. They get more freedom in choosing the means and methods of learning. The learning process is also treated as a social process, despite the fact, that every person constructs his own and interprets the reflections of the world individually, the social aspect of learning takes a very important place in the theory. While cooperating with others, the student gains new knowledge and skills, forms his own attitudes, constructs interpersonal relations and expands social ability.

"ARiSE" teaching / learning platform will make conditions to organize learning appealing on constructive approach, i.e. to construct and interpret individual experience actively while interacting with a mixed learning surrounding and the partners of learning / teaching process - contemporaries and teachers. 


\section{Summing-up}

Augmented reality is created using computer display which affects the senses of a user and gives additional information. The majority of the AR research papers focused on developing a visual device inserting picture / text into the field of vision of a user. Visual information covering other senses such as volume or touch is also possible.

The project "AriSE" will implement three prototypes based on three teaching /learning and interaction scenarios. Prototype 1 is targeting Biology and has been tested with users during the $1^{\text {st }}$ summer school held in Hamrun, Malta in November 2006.

It is obvious, that new AR platform has a large possibilities. It is necessary to expand opportunities from the point of view of practical application in daily school life. The further technical improvement of the given technology should be carried out on the basis of results of pedagogical researches. At the given stage efficiency of new technology can be proved based on different pedagogical and psychological theories such as Action Learning, Learning by Doing, Problem-based Learning, Flexible Learning ect.

\section{References}

Arends, R.I. (1998). Mokomés mokyti. Vilnius.

Azuma, R. (1997). “A Survey of Augmented Reality” PRESENCE: Teleoperators and Virtual Evironments, Vol. 6, No. 4, p. 355-385.

Bailer-Jones, D. M. (1999). Tracing the development of models in the philosophy of science. In: Magnani L., Nersessian N.J. \& Thagard P. (Ed.), Model-based reasoning in scientific Discovery. P. 2340. New York: Kluwer Academic Publishers.

Brill, J. M. (2001). Situated cognition. In M. Orey (Ed.), Emerging perspectives on learning, teaching, and technology. Available in the internet $<$ http://www.coe.uga.edu/ $>$

Brown, J.S., Collins A., Dugid P. (1989). Situated cognition and the Culture of Learning. Educational Researcher, 18, p. 32-42.

Butcher-Powell, L.M. (2004). Teaching, Learning and Multimedia. In.: Interactive Multimedia inEducation and training. Sanjaya Mishra \& Ramesh C. Sharma (Ed.), Yurchak Printing Inc. P. 60-72.

David, A. Wheeler (January 2, 2007). The Most Important Software Innovations. (2007-05-06). Available in the internet: $<$ http://www.dwheeler.com/innovation/innovation.html $>$

Description of Work /DofW/. (2005). $6^{\text {th }}$ Framework Programme - Priority 2 "Information Society Technologies", Call identifier: FP6-2004-IST-4; Proposal Nº 027039 - ARiSE: Augmented Reality in School Environments (unpublished manuscript).

Driver R. (1989). Changing conceptions. In: Adey, P. (Ed.), Adolsescent Development and School Science. London: Falmer.

Duoblienè, L. (2006). Šiuolaikinè ugdymo filosofija: refleksijos ir dialogo link. Vilnius.

Francoeur, E. (1997). The forgotten tool: the design and use of molecular models. Social Studies of Science, 27, p. 7-40.

Gadamer, H. G. (1989). Truth and Method. Continuum International Publishing Group. P. 270312.

Gallagher, S. (1992). Hermeneutics and Education. New York: State University of New York Press.

Gilbert, J. K., Boulter, C. J., \& Rutherford M. (2000). Explanations with Models in Science Education. In.: J. K. Gilbert \& C. J. Boulter (Ed.), Developing Models in Science Education P. 193-208. Dordrecht: Kluwer.

Glasesfeld, E. (1991). Knowing without metaphysics: aspects of the radical constructyvist psotion. In: Steier, F. (Ed), Research and Reflexivity. London: Sage.

Hermeneutika. [žiūrèta 200701 20]. Available in the internet: <http://lt.wikipedia.org/wiki/Hermeneutika>

Hodson, D. (1992). In search of a meaningful relationship: an exploration of some issues relating to integration in science education. International Journal of Science Education, 14(5), p. 541-562. 
Holding, B. At al. (1990). Interactive Teaching in Science: Workshops for Training Courses, Workshop 9: Diagnostic teaching in science classrooms, CLIS project. Hatfield: Association for Science Education.

Ignatova, N. (2007). Švietimo ateities vizija IKT ir inovacijų kontekste. Available in the internet: http://inovacijos.pedagogika.lt/lt/naujienos/files/Natalija

Lamanauskas, V. (2003). Gamtamokslinis ugdymas pradineje mokykloje. Šiauliai.

Lamanauskas, V. (2006). Some features of modern ICT. In.: Information \& Communication Technology in Natural Science Education - 2006 (Proceedings of International Scientific Practical Conference). Siauliai.

Lamanauskas V., Vilkonis R. (2007). Pedagogical Evaluation of the New Teaching/Learning Platform Based on Augmented Reality Technology: Prototype 1. In.: V.Lamanauskas \& G.Vaidogas (Eds.), Science and Technology Education in the Central and Eastern Europe: Past, Present and Perspectives (The proceedings of $6^{\text {th }}$ IOSTE Symposium for Central and Eastern Europe). Siauliai: Siauliai University Press, p. 88-97.

Laugksch, R. C. (2000). Scientific literacy: a conceptual overview. Science Education, 84 (1). p. 71-94.

Liarokapis, F., Mourkoussis, N., White, M., Darcy, J., Sifniotis, M., Panos Petridis, P., Basu, A. \& Lister, P. (2004). Web3D and augmented reality to support engineering education. In.: World Transactions on Engineering and Technology Education, Vol.3, No.1.

Lyotard, J. F., (1993). Postmodernus būvis:šiuolaikini žinojima aptariant. Vilnius.

Müehl, J.K. (2005). Augmented Reality in School Environments (ARiSE). Project outline (Contribution to EU-Call IST4 within FP6, Call Identifier FP6-2004-IST-4) /unpublished manuscript).

Müehl, J.K. (2006). A user-centered approach to computer supported teaching in classroom environments. In.: Information and Communication Technology in Natural Science Education - 2006 (Proceedings of International Scientific Practical Conference). Šiauliai. Šiauliai University Press, p. 7176.

Papert, S. (1980). Mindstorms: Children, Computers, and Powerful Ideas. New York: Basic Books.

Peterson, M. P. (1994). Cognitive issues in cartographic vizualization. In.: A. M. Maceachren \& D. F. Taylor (Ed.), Visualization in Modern Cartography.). Oxford: Pergamon, P. 27-43.

Rorty, R. (1997). Atsitiktinumas, ironija ir solidarumas. Kultūros barai, Nr. 7-8.

Šlekienè, V., Ragulienè, L. (2006). The Analysis of pupils‘ pre-scientific notions and scientific concepts about motion and forces. Gamtamokslinis ugdymas/Natural Science Education, Nr. 2(16). p.1724.

Received 05 May 2007; accepted 22 August 2007

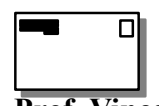

Prof. Vincentas Lamanauskas,

Natural Science Education Research Centre,

University of Siauliai,

P. Visinskio Street 25-119, LT-76351 Siauliai, Lithuania

E-Mail: vincentas@,osf.su.lt

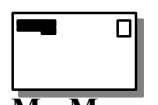

Ms. Margarita Vilkonienė,

Natural Science Education Research Center, Faculty of Education, University of Siauliai, P. Visinskio Street 25-119, LT-76351 Siauliai, Lithuania

E-Mail: vilkarira@yahoo.com

\section{Dr. Rytis Vilkonis,}

Faculty of Education, University of Siauliai,

P. Visinskio Street 25-119, LT-76351 Siauliai, Lithuania

E-Mail: vilkonis@yahoo.com 